\title{
Article \\ Effect of Chitosan Composite Coatings with Salicylic Acid and Titanium Dioxide Nanoparticles on the Storage Quality of Blackcurrant Berries
}

\author{
Yage Xing ${ }^{1, *(D)}$, Tianyi Yue ${ }^{2}$, Yu Wu ${ }^{2}$, Qinglian Xu ${ }^{1}$, Xunlian Guo ${ }^{1}$, Xiaomin Wang ${ }^{2}$, Shuang Yang ${ }^{2}$, Lin $X u^{2}$ \\ and Ping Yang ${ }^{2}$
}

check for updates

Citation: Xing, Y.; Yue, T.; Wu, Y.; Xu, Q.; Guo, X.; Wang, X.; Yang, S.; $\mathrm{Xu}$, L.; Yang, P. Effect of Chitosan Composite Coatings with Salicylic Acid and Titanium Dioxide Nanoparticles on the Storage Quality of Blackcurrant Berries. Coatings 2021, 11, 738. https://doi.org/10.3390/ coatings 11060738

Received: 1 June 2021

Accepted: 18 June 2021

Published: 21 June 2021

Publisher's Note: MDPI stays neutral with regard to jurisdictional claims in published maps and institutional affiliations.

Copyright: (c) 2021 by the authors. Licensee MDPI, Basel, Switzerland. This article is an open access article distributed under the terms and conditions of the Creative Commons Attribution (CC BY) license (https:/ / creativecommons.org/licenses/by/ $4.0 /)$.
1 Key Laboratory of Grain and Oil Processing and Food Safety of Sichuan Province, College of Food and Bioengineering, Xihua University, Chengdu 610039, China; xuqinglian01@163.com (Q.X.); gx1412326@163.com (X.G.)

2 Key Laboratory of Food Non-Thermal Technology, Engineering Technology Research Center of Food Non-Thermal Processing, Yibin Xihua University Research Institute, Yibin 644004, China; tianyiyue1@163.com (T.Y.); yty354666071@163.com (Y.W.); xiaominwang99@126.com (X.W.); 18383138661@163.com (S.Y.); xulin6280@163.com (L.X.); ypedu0119@163.com (P.Y.)

* Correspondence: xingyage1@163.com

\begin{abstract}
The use of chitosan and chitosan composite coatings for the preservation of fruits and vegetables during storage is attracting increasing attention. In this study, a chitosan-based edible coating, as well as a second chitosan-based edible coating containing salicylic acid (CTS + SA), a third containing nanosized titanium dioxide particles $\left(\mathrm{CTS}+\mathrm{TiO}_{2}\right)$, and a fourth containing a combination of these two $\left(\mathrm{CTS}+\mathrm{SA}+\mathrm{TiO}_{2}\right)$ were evaluated in terms of their effects on the postharvest quality of blackcurrant fruit during storage at $4{ }^{\circ} \mathrm{C}$. The results showed that compared with the other three treatment groups, the blackcurrants treated with $\mathrm{CTS}+\mathrm{SA}+\mathrm{TiO}_{2}$ underwent the smallest changes in weight loss, total soluble solids, titratable acidity, vitamin $\mathrm{C}$, and total anthocyanin content, and retained the highest total flavonoid content. This combined treatment significantly inhibited polyphenol oxidase activity during storage, and the $\mathrm{CTS}+\mathrm{SA}+\mathrm{TiO}_{2}$ samples also displayed the lowest malondialdehyde content. These results, thus, indicate that the $\mathrm{CTS}+\mathrm{SA}+\mathrm{TiO}_{2}$ composite coating could maintain the nutrient composition of blackcurrants, thereby playing a significant role in preserving the quality of this fruit at $4^{\circ} \mathrm{C}$.
\end{abstract}

Keywords: blackcurrant; chitosan; salicylic acid; nano- $\mathrm{TiO}_{2}$; quality

\section{Introduction}

Blackcurrant (Ribes nigrum L.) is one of Europe's most important berry crops [1], renowned for its considerable potential health benefits, particularly its high levels of ascorbic acid and antioxidant activity [2,3]. Blackcurrant berries are widely used to produce jam, juice, wine, liqueur and spirits [4], all products that are increasingly popular among consumers, not only in Europe and the USA but also, more recently, in China. This is because of the fruit's extremely high bioactive compounds such as vitamin $C$, which is four times more concentrated than it is in oranges and 50 times more so than in apples [5]. Consuming blackcurrant products in moderation can provide anti-inflammatory, antioxidant, and antimicrobial effects that are beneficial to human health [6-8]. However, fresh fruits deteriorate rapidly after harvesting due to their loss of water and cellular juice, and senescence [9]. Moreover, in conditions of high humidity, fungal infection can result in sensorial and nutritional damage [10]. Recently, efforts to preserve the shelf-life of fruit have focused on replacing chemical and synthetic preservatives with natural alternatives, and several environmentally friendly methods have been suggested to maintain fruit quality, including those using carbohydrate-based polymers, such as chitosan [11,12]. 
Chitosan is the most common cationic polysaccharide and is a renewable resource, abundantly available as a low-cost biopolymer [13]. It is widely utilized as a protective coating for a variety of fruits and vegetables after harvesting $[9,14,15]$, for example, to control the decay and bacteriostasis of citrus fruits during storage [16], and to prevent dehydration during handling and packaging [17]. Furthermore, chitosan can also be combined with other biopolymers to increase and assure the effectiveness of crop coatings [12,18,19]. The results of Kaya et al. [20], for example, indicated that the use of a chitosan-acetic acid coating might be an effective technology for prolonging the short shelf-life of red kiwifruit berries, while Hernandez et al. [21] demonstrated that a chitosan coating with a postharvest calcium treatment can improve the firmness of strawberries. Moreover, applications of chitosan and essential oils, antibacterial nanoparticles, and other active ingredients have also been reported in studies on jujubes, strawberries, and apples [14,22,23].

Titanium dioxide $\left(\mathrm{TiO}_{2}\right)$ has attracted a great deal of attention as an inorganic bacteriostatic, and it has become widely used as a self-disinfecting and self-cleaning material in diverse applications [24,25]. The American Food and Drug Administration (FDA) has approved and recommends the use of $\mathrm{TiO}_{2}$ in healthcare, cosmetics and food materials due to its low toxicity [26]. According to expert research, chitosan- $\mathrm{TiO}_{2}$ composite materials exhibit multifunctional performance in many potential applications, such as wastewater treatment [27], as well as antimicrobial activity [24,28]. Moreover, it has been found that the nano metals used as polymer-forming membranes in $\mathrm{TiO}_{2}$ particles act as a reinforcing compound to provide substantial mechanical strength to scaffolds for the support of cell growth [29].

Salicylic acid (SA), a phenolic compound, is used to enhance the local and systemic resistance of fruits against pathogens [30], thus playing an important role in aspects of fruit quality, such as firmness, taste, aroma and color [31]. In one study, SA was applied to improve the quality of sweet cherries at harvest time by expanding the fruit's phenolic and anthocyanin synthesis, and aggregating cell antioxidant activities [32]. In addition, SA treatment has shown its effects on promoting the quality of peaches [33], resulting in a higher flavonoid content and increased phenylalanine ammonia-lyase (PAL) activity [34], and inhibiting the production of ethylene, respiration and senescence [35].

The application of chitosan composited with active functional substances has attracted increasing interest, due to their superior antimicrobial activity to maintain the quality attributes of fruit [28,36-38]. The results of Tian et al. [39] suggested that composite coatings of chitosan $/$ nano- $\mathrm{TiO}_{2}$ can effectively maintain the quality of Ginkgo biloba seeds (reducing decay and shrinkage rate, and prolonging firmness), and they were also found to extend the shelf-life of ginkgo seeds and mango fruits [40]. Moreover, the combination of chitosan and $\mathrm{TiO}_{2}$ film is reported to be highly effective at controlling mold and yeast population growth [29], phenol enzymes, total soluble sugars and malondialdehyde in ready-to-eat cantaloupe [37]. According to Cui et al. [38], the combination of chitosan and SA in preharvest treatments significantly maintained the postharvest quality of Xiaobai apricots during storage. Other experimental data suggest that chitosan coatings containing SA effectively reduce bacterial and fungal counts in fresh pistachio fruit [41]. In summary, many researchers have reported that chitosan and chitosan composites with active substances can effectively protect the quality attributes of fresh fruits and vegetables and prolong their shelf life.

However, from the literature review, it is apparent that not many studies have investigated the effects of chitosan and chitosan composite coatings on the storage quality of blackcurrants. This study, therefore, aims to examine the effects of chitosan acetate coatings alone, in combination with $\mathrm{SA}$, in combination with $\mathrm{TiO}_{2}$, and in combination with both these active substances, on the quality attributes of blackcurrants during storage. Assessments of these treatments are based on the fruit qualities of weight loss, total soluble solids (TSS), titratable acidity (TA), vitamin C (VC) and malondialdehyde (MDA) content, polyphenol oxidase (PPO) activity, total anthocyanin content (TAC), total flavonoid content (TFC), and microbiological qualities. 


\section{Materials and Methods}

\subsection{Materials}

Commercially mature blackcurrant (Ribes nigrum L.) berries were obtained from the Fresh store in Chengdu City, Sichuan, China. Fruits were selected based on uniform color, size, hardness, and lack of visible physical damage or fungal infection. The blackcurrants were transferred immediately to the laboratory, where, after having been washed three times in distilled water, they were surface-disinfected via immersion in a $5 \%$ sodium hypochlorite aqueous solution and dried at room temperature. The chitosan powder (deacetylated $\leq 95 \%$ ) was provided by Jinan Haidebei Marine Bioengineering Co. Ltd. (Jinan, China). Nano- $\mathrm{TiO}_{2}(20-30 \mathrm{~nm}$ ) was obtained from the Beijing Deke Island Gold Technology Co. Ltd. (Beijing, China). SA, sodium laurate, phosphate buffer, glacial acetic acid, glycerol, sodium hydroxide, sodium hypochlorite, phenolphthalein, ethanol, hydrochloric acid, trichloroacetic acid, thiobarbituric acid, methanol, sodium nitrite, aluminum nitrate, anhydrous sodium acetate, polyvinylpyrrolidone, catechol, sodium chloride, Rutin standard product and L-ascorbic acid were purchased from the Chengdu Kelon Chemical Reagent Factory (Chengdu, China).

\subsection{Preparation of Chitosan and Chitosan-Based Coatings}

The chitosan solution (CTS) was prepared according to the method of Han et al. [42], with some modifications. Briefly, $1 \mathrm{~g}$ of chitosan powder was dissolved in $100 \mathrm{~mL}$ aqueous solution of $1 \%(v / v)$ glacial acetic acid with $1 \mathrm{~g}$ glycerin placed on the magnetic heating agitator (WS-2A, Changzhou Yuexin Instrument Manufacturing Co. Ltd., Changzhou, China) at $90{ }^{\circ} \mathrm{C}$ and $500 \mathrm{rpm} / \mathrm{min}$ for $25 \mathrm{~min}$. The mixture was then filtered through eight layers of cheesecloth and exposed to ultrasound for $30 \mathrm{~min}$ to finally produce the CTS.

The nano- $\mathrm{TiO}_{2}$ modification was performed according to the method developed by Xing et al. [43]. Briefly, $1 \mathrm{~g}$ nano- $\mathrm{TiO}_{2}$ was dispersed in $100 \mathrm{~mL}$ of $0.050 \mathrm{~mol} / \mathrm{L}$ sodium laurate solution, the $\mathrm{pH}$ was adjusted to 5.0 , and the mixture was stirred at $40 \pm 2{ }^{\circ} \mathrm{C}$ for $30 \mathrm{~min}$. The solution was then filtered, rinsed, and dried in an oven for $1 \mathrm{~h}$, finally resulting in the modified sodium laurate nano- $\mathrm{TiO}_{2}$.

The CTS + SA solution was prepared according to the method of Zhang et al. [44], with some modifications. Briefly, $0.1 \%(w / v)$ SA and $1 \%(w / v)$ CTS were dispersed in an aqueous solution of glacial acetic acid $(1 \%, v / v)$, and the subsequent process was the same as that employed for the preparation of the pure chitosan film.

The CTS + $\mathrm{TiO}_{2}$ solution was prepared using the method of Xing et al. [40], with some modifications. The $0.03 \mathrm{~g}$ sodium laurate modified nano- $\mathrm{TiO}_{2}$ was dissolved in $1 \mathrm{~g}$ glycerin, followed by the sequential addition of $100 \mathrm{~mL} 1 \%$ aqueous acetic solution and $1 \mathrm{~g}$ chitosan powder. The subsequent steps were the same as those employed during the preparation of the pure chitosan film.

For the CTS + SA $+\mathrm{TiO}_{2}$ solution, the formulation ration was as follows: CTS: SA: $\mathrm{TiO}_{2}=1: 0.1: 0.03(w / w / w)$. The preparation procedure was the same as that employed to prepare the pure chitosan film.

\subsection{Sample Processing}

Blackcurrants were randomly distributed into five groups, one of which provided an untreated control (CK), while the other four were assigned to the following treatments: a chitosan coating group (CTS), a chitosan + salicylic acid coating group (CTS + SA), a chitosan + nano- $\mathrm{TiO}_{2}$ coating group $\left(\mathrm{CTS}+\mathrm{TiO}_{2}\right)$, and chitosan + salicylic acid nano$\mathrm{TiO}_{2}$ coating group $\left(\mathrm{CT}+\mathrm{SA}+\mathrm{TiO}_{2}\right)$. Each group contained $1.5 \mathrm{~kg}$ of fruit. The berries were immersed in the respective membrane solutions, prepared as described above, for $2 \mathrm{~min}$, with the control samples dipped in distilled water. They were then dried at room temperature and sealed in micro-perforated bags (PLA) bags to maintain aerobic conditions and limit fruit dehydration, after which they were placed in polyethylene terephthalate (PET) plastic trays and stored at $4{ }^{\circ} \mathrm{C}$ and $75 \%$ relative humidity for 30 days. 


\subsection{Weight Loss}

To determine the weight loss of blackcurrant fruit during postharvest storage, both treated and control fruits were weighed at different sampling intervals. Then, weight loss was calculated as the difference between the initial fruit weight and the fruit weight at the time of measurement, and expressed as a percentage (\%) [45].

\subsection{Determination of Total Soluble Solids, Titratable Acidity, Vitamin C}

TSS content in the fruit pulp juice was measured using an Abbe refractometer (2WAJ, Shanghai Optical Instrument Co. Ltd., Shanghai, China). Briefly, a 10-g blackcurrant sample was ground in a mortar and filtered, and the resultant juice was analyzed, with the values expressed as percentages. TA content, expressed as a percentage of citric acid, was determined by titration using a standard solution of sodium hydroxide $(0.1 \mathrm{M})$ [46]. VC was also assayed by the titration, using a solution of 2,6-dichlorophenolindophenol as described by Gao et al. [47], with some modifications. Briefly, a mixture of $10 \mathrm{~g}$ blackcurrant fruit and $10 \mathrm{~mL}$ oxalic acid was ground into juice on a mortar, followed by the addition of $5 \mathrm{~g}$ of porcellanite, and it was left to stand for $20 \mathrm{~min}$ before being filtered. Values were expressed in $\mathrm{mg}$ of ascorbic acid per $100 \mathrm{~g}$ of fresh blackcurrant.

\subsection{Determination of Malondialdehyde Content}

The MDA content in the blackcurrant groups was determined via thiobarbituric acid (TBA) reaction, as described by $\mathrm{Xu}$ et al. [24], with slight modifications. Briefly, $4 \mathrm{~g}$ pulp was dissolved in $20 \mathrm{~mL}$ trichloroacetic acid and the mixture was centrifuged for $15 \mathrm{~min}$ at $4000 \mathrm{rpm}$. A $2 \mathrm{~mL}$ sample of the supernatant was mixed with $2 \mathrm{~mL}$ of $6.7 \mathrm{~g} \mathrm{~L}^{-1} \mathrm{TBA}$, heated at $100{ }^{\circ} \mathrm{C}$ for $30 \mathrm{~min}$, then quickly cooled in an ice bath and further centrifuged at $4000 \mathrm{rpm}$ for $15 \mathrm{~min}$. Supernatant absorbances were measured at 450, 532 and $600 \mathrm{~nm}$, respectively. The MDA content was calculated according to the following formula: $\mathrm{C}\left(\mu \mathrm{mol} \mathrm{L}{ }^{-1}\right) \mathrm{MDA}$ $=6.451 \times(\mathrm{A} 532-\mathrm{A} 600)-0.56 \times \mathrm{A} 450$, where A450, A532 and A600 are the absorbencies of the solution at 450, 532 and $600 \mathrm{~nm}$, respectively.

\subsection{Polyphenol Oxidase Activity Analysis}

PPO activity was measured using the methods described by Xiao et al. [25], with some modifications. Briefly, $5 \mathrm{~g}$ blackcurrant samples were ground at ice-cold temperatures in a mortar and pestle containing $50 \mathrm{~mL}$ of $0.05 \mathrm{M}$ potassium dihydrogen phosphate buffer ( $\mathrm{pH}$ 6.8). After rapid homogenization, the mixture was centrifuged at $8000 \mathrm{rpm}$ for $15 \mathrm{~min}$ at $4{ }^{\circ} \mathrm{C}$ in a Heraeus Multifuge X1R refrigerated centrifuge (Thermo Fisher Scientific, Waltham, MA, USA). The clear supernatant was used to determine enzyme activity. The enzyme solution $(0.2 \mathrm{~mL}$ ) was added to a mixture of $3 \mathrm{~mL}$ of $0.05 \mathrm{M}$ phosphate buffer (pH 6.8), and $1 \mathrm{~mL}$ of $0.04 \mathrm{M}$ catechol as substrate. PPO activity was measured in a spectrophotometer (WFJ7200, UNIC (Shanghai) Equipment Co. Ltd., Shanghai, China) at $398 \mathrm{~nm}$. The units of enzyme activity were defined as a change of 0.01 in the absorbance value per minute under the conditions of the assay. Each determination was run in triplicate.

\subsection{Determination of Total Flavonoid Content and Total Anthocyanin Content}

Briefly, $5 \mathrm{~g}$ blackcurrant pulp was placed into a precooled $50 \mathrm{~mL}$ centrifuge tube containing 1\% HCL-methanol solution (approximately $20 \mathrm{~mL}$ ), and homogenized in an ice bath. The homogenate was then transferred to a $50 \mathrm{~mL}$ volumetric flask, the volume was fixed with $1 \% \mathrm{HCL}$-methanol solution, shaken well, and then placed in the dark at $4{ }^{\circ} \mathrm{C}$ for $20 \min [48]$.

TFC was estimated as described by $\mathrm{Xu}$ et al. [49], with slight modification. A $10 \mathrm{~mL}$ glass tube containing $2 \mathrm{~mL}$ of the diluted extract was prepared, to which $1 \mathrm{~mL}$ of $5 \% \mathrm{NaNO}_{2}$ solution was added, and it was left to stand for $6 \mathrm{~min} .1 \mathrm{~mL}$ of $10 \% \mathrm{Al}\left(\mathrm{NO}_{3}\right)_{3}$ and $3 \mathrm{~mL}$ of $4 \% \mathrm{NaOH}$ solution were added, and then $3 \mathrm{~mL}$ of $70 \%$ ethanol was added to the reaction mixture. After being left to stand for a further $10 \mathrm{~min}$, the absorbance was measured at $510 \mathrm{~nm}$ using a spectrophotometer (WFJ7200, UNIC (Shanghai) Equipment Co. Ltd., 
Shanghai, China). A blank was prepared by replacing the sample with 1\% HCL-methanol solution. The TFC was represented as milligrams of rutin equivalents per gram of fresh weight (mg RE/g FW). All analyses were performed in triplicate.

The $\mathrm{pH}$-differential method was used to determine the TAC of the blackcurrants, according to the details of this analysis described by Johnson et al. [50]. Aqueous buffer solutions at $\mathrm{pH} 1$ and $\mathrm{pH} 4.5$ were prepared from $0.025 \mathrm{M}$ potassium chloride and $0.4 \mathrm{M}$ sodium acetate, respectively, with the $\mathrm{pH}$ adjusted using concentrated $\mathrm{HCl}$. A sample extract $(2 \mathrm{~mL})$ was then mixed with $8 \mathrm{~mL}$ buffer and, after equilibration at room temperature in darkness for $40 \mathrm{~min}$, the absorbances at $510 \mathrm{~nm}$ and $700 \mathrm{~nm}$ were read using a UVvisible spectrophotometer (WFJ7200, UNIC (Shanghai) Equipment Co. Ltd., Shanghai, China), with 1\% HCL-methanol solution used as the blank. The monomeric anthocyanin concentration was calculated using the following formula:

$$
\text { mg cyd-3-glu } \mathrm{L}^{-1}=(A \times M W \times D F \times 1000) /(\varepsilon \times 1)
$$

where $A=(\mathrm{pH} 1: \mathrm{A} 510-\mathrm{A} 700)-(\mathrm{pH} 4.5$ : A510 $-\mathrm{A} 700), D F$ is the dilution factor $(10 \times$ following the procedure given), $M W$ is the molecular weight $=449.2 \mathrm{~g} / \mathrm{mol}$ for cyaniding-3glucoside, $\varepsilon$ is the molar extinction coefficient $=26,900 \mathrm{~L} / \mathrm{cm}$, and 1 is the path length $(1 \mathrm{~cm})$. The reactions were performed in triplicate and the results were calculated as milligram cyaniding-3-O-glucoside equivalents per $100 \mathrm{~g}$ of fresh weight (FW).

\subsection{Measurement of the Aerobic Mesophilic Bacteria}

Microbiological analysis was performed as described by Bico et al. [51]. A $10 \mathrm{~g}$ sample slice was blended with $90 \mathrm{~mL}$ sterile solution for $60 \mathrm{~s}$ using a Stomacher. The sample solution ( $1 \mathrm{~mL}$ ) at an appropriate dilution was pour-plated into plate count agar (PCA), and then incubated at $37^{\circ} \mathrm{C}$ for $24 \mathrm{~h}$, after which the aerobic mesophilic bacteria were identified. The results were expressed in $\log \mathrm{CFU} / \mathrm{g}$.

\subsection{Statistical Analysis}

Completely randomized designs were used in triplicate, both in measurements and analyses in this study, and this investigation was carried out in triplicate. Test results were analyzed using SPSS 20.0 statistics software (IBM USA) and expressed as mean \pm standard deviation, while the figures were generated using Origin 2017 (OriginLab Corporation, Northampton, MA, USA).

\section{Results}

\subsection{Weight Loss}

In this study, all the treatments using chitosan, both alone and in combination, were found to be highly effective in minimizing the weight loss of blackcurrant fruit during storage at $4{ }^{\circ} \mathrm{C}$, compared to $\mathrm{CK}$ (Figure 1). Irrespective of treatments, however, weight loss increased progressively with the advancement of storage to 30 days. Of the five different treatments, the maximum weight loss $(11.49 \%)$ was recorded in CK fruits, significantly higher than other treatment groups $(p<0.05)$, followed by the CTS $(9.90 \%)$, $\mathrm{CTS}+\mathrm{TiO}_{2}(8.24 \%)$, and CTS $+\mathrm{SA}(8.10 \%)$ groups of blackcurrants. The fruit treated with $\mathrm{CTS}+\mathrm{SA}+\mathrm{TiO}_{2}$ showed the least weight loss $(7.47 \%)$ at the end of the full storage period $(p<0.05)$.

Weight loss in post-harvest blackcurrant fruit occurs primarily due to the rapid loss of moisture from the pericarp tissues [45]. This moisture loss leads to the development of micro-cracks in the fruit pericarp, which move progressively inward up to the parenchymatous mesocarp [52], inducing further moisture loss, pathogen attack, and the rapid browning of the pericarp [45]. In this study, chitosan alone, and in combination with SA and nano- $\mathrm{TiO}_{2}$, reduced weight loss in the blackcurrants comparatively more than the CK. SA has been reported to reduce moisture loss by closing the stomata in fruits like mandarins [53], while CTS combined with $\mathrm{TiO}_{2}$ has also been reported to effectively prevent water loss [40]. Chitosan treatment provides an additional barrier against the diffusion 
of gases and water vapor. Thus, the chitosan combination treatment with $\mathrm{SA}$ and $\mathrm{TiO}_{2}$ might have exerted a synergistic effect in preventing the loss of moisture and gases in the blackcurrants, consequently reducing weight loss during storage.

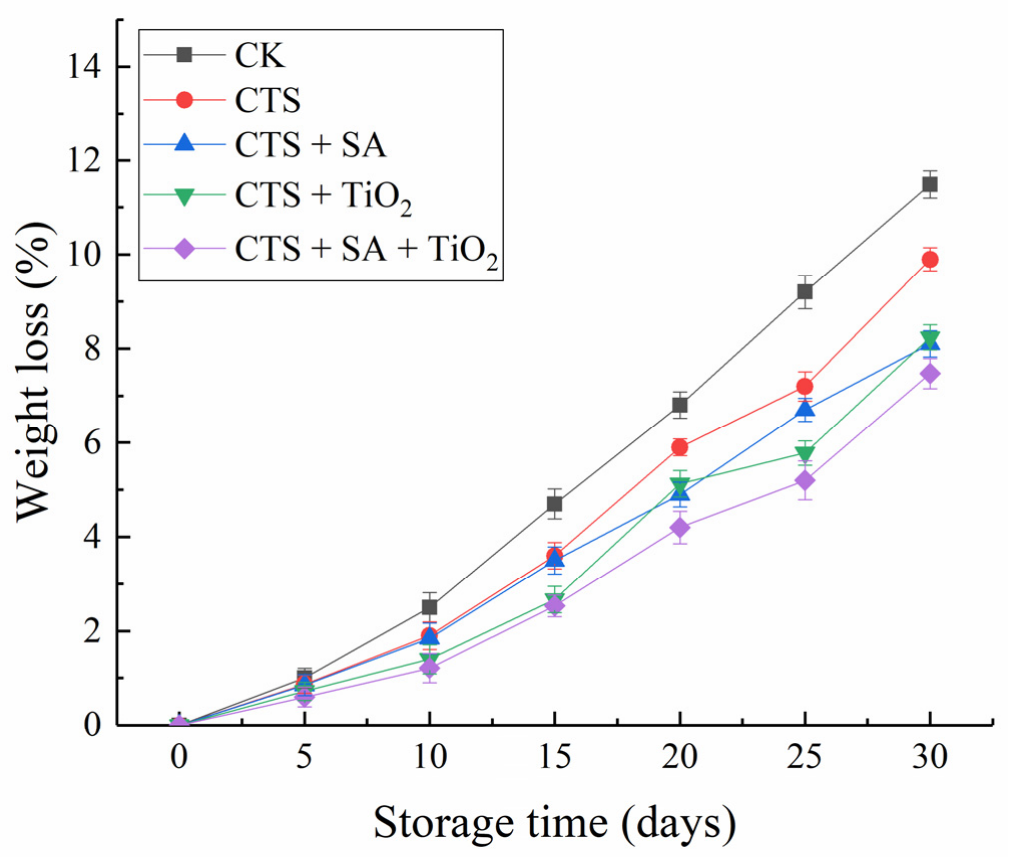

Figure 1. Effect of chitosan and chitosan composite coatings on weight loss (\%) of blackcurrant fruit during storage.

\subsection{TSS, TA and VC}

Changes in the contents of TSS, TA and VC in the blackcurrants during storage were investigated in this study and shown in Figure 2, and were found to be different depending on the fruit coating treatment. In all groups, the TSS content increased during storage (Figure 2a), however, in the CK group, TSS increased most rapidly and continuously, reaching $18.13 \mathrm{Brix}^{\circ}$, followed by the $\mathrm{CTS}, \mathrm{CTS}+\mathrm{TiO}_{2}, \mathrm{CTS}+\mathrm{SA}$, and $\mathrm{CTS}+\mathrm{SA}+\mathrm{TiO}_{2}$ groups, in which the TSS content values reached $17.80 \mathrm{Brix}^{\circ}, 17.57 \mathrm{Brix}^{\circ}, 17.33 \mathrm{Brix}^{\circ}$ and $17.02 \mathrm{Brix}^{\circ}$, respectively, at the end of the storage period. These results demonstrate that the coating treatment can effectively slow down the rate of TSS $(p<0.05)$. As shown in Figure $2 b$, the TA content of all groups also followed the same trend, showing an increase in the first five days; however, the $\mathrm{CTS}+\mathrm{SA}+\mathrm{TiO}_{2}$ group showed the fastest increase, reaching $1.98 \%$ in the remaining 25 days, after which its TA content showed a continuous decline. On the last day of storage, the groups with the highest to lowest levels of TA were $\mathrm{CTS}+\mathrm{SA}+\mathrm{TiO}_{2}(1.73 \%), \mathrm{CTS}+\mathrm{TiO}_{2}(1.63 \%), \mathrm{CTS}+\mathrm{SA}(1.60 \%), \mathrm{CTS}(1.52 \%)$, and CK $(1.43 \%)$. These results show that the coating treatment can significantly inhibit the decrease of TA content $(p<0.05)$. The VC content in all five groups gradually decreased during storage (Figure 2c), with the decrease in the CK fruit most remarkable $(p<0.05)$ and the $\mathrm{CTS}+\mathrm{SA}+\mathrm{TiO}_{2}$ group showing the slowest decline $(p<0.05)$. The initial value of $\mathrm{VC}$ content in the fresh blackcurrants was $128 \mathrm{mg} / 100 \mathrm{~g}$, but by the end of storage time, the VC contents of the $\mathrm{CTS}+\mathrm{SA}+\mathrm{TiO}_{2}, \mathrm{CTS}+\mathrm{SA}, \mathrm{CTS}+\mathrm{TiO}_{2}, \mathrm{CTS}$ and $\mathrm{CK}$ groups had declined to $99.10 \mathrm{mg} / 100 \mathrm{~g}, 91.87 \mathrm{mg} / 100 \mathrm{~g}, 89.12 \mathrm{mg} / 100 \mathrm{~g}, 87.68 \mathrm{mg} / 100 \mathrm{~g}$, and $83.99 \mathrm{mg} / 100 \mathrm{~g}$, respectively. 
(a)
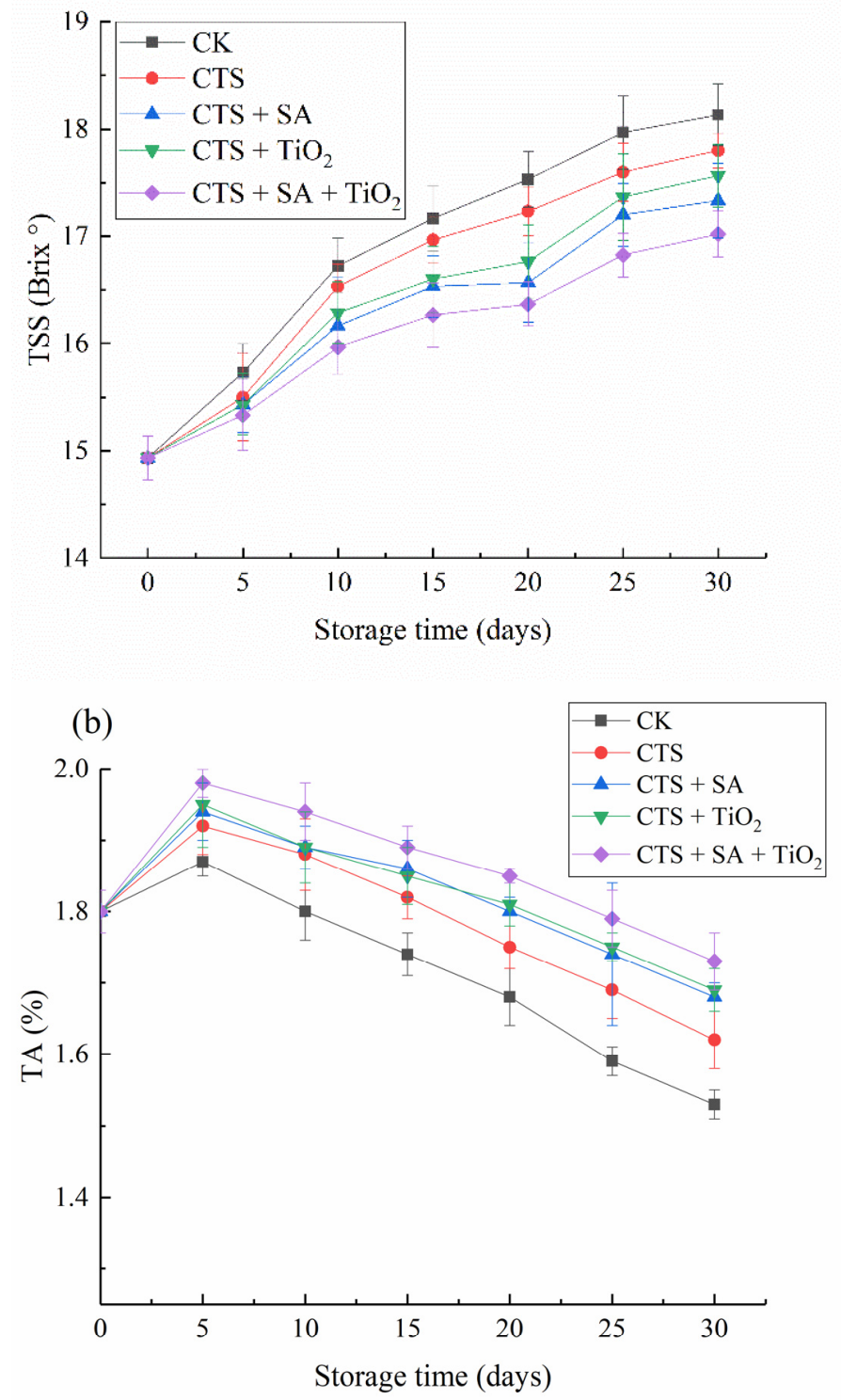

(c)

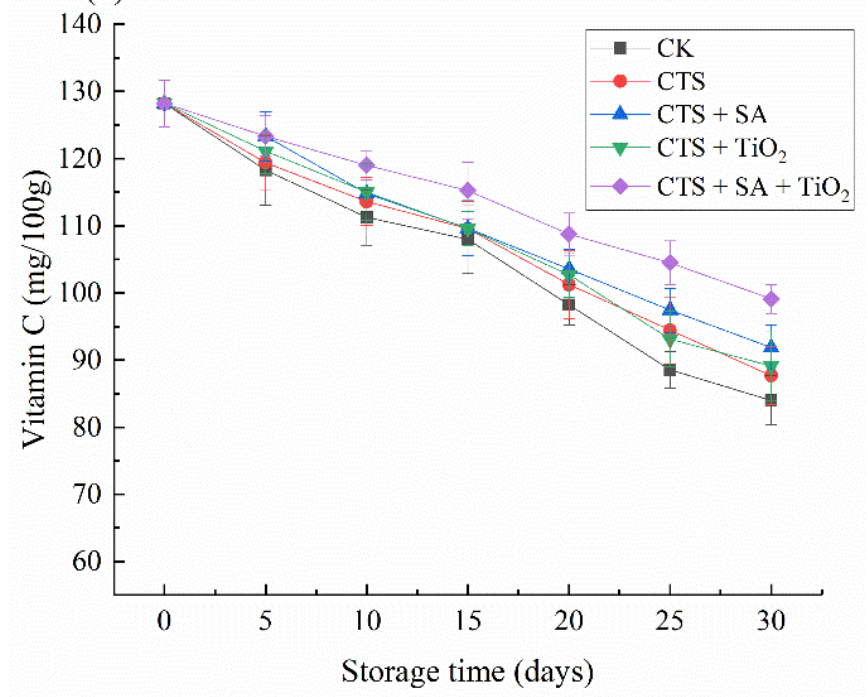

Figure 2. Total soluble solids content: (a), titratable acid content (b), VC content (c) of the samples during 30-day storage at $4{ }^{\circ} \mathrm{C}$. 
The main quality indexes of blackcurrant fruit include the TSS, TA and VC content, and these have been shown to change dynamically during postharvest storage [32]. In particular, TSS represents the degree of ripening in fruits [54], and comprises sugar, a small amount of acid, vitamins, minerals and some soluble pectin [55]. In this study, the TSS content increased in all treatment groups during the storage, probably due to ripening and loss of water [36]. All the groups treated with chitosan and chitosan composite coatings were found to have a lower TSS content than the CK group. This is consistent with the result reported by Xing et al. [40], in which a slow rise in TSS content was recorded in mango treated with chitosan composited with nano- $\mathrm{TiO}_{2}$. The capacity of chitosan to inhibit the rapid increase of TSS content could be attributed to a decline in respiration and metabolic activity, which consequently delays the ripening process. The lowest TSS content was observed in the group treated with the CTS $+\mathrm{SA}+\mathrm{TiO}_{2}$ coating, possibly due to the presence of $\mathrm{SA}$ and nano- $\mathrm{TiO}_{2}$. SA treatment is reported to inhibit the ripening progress of fruit by directly interfering with signaling pathways [56] and ethylene biosynthesis [57]. Respiration, a major postharvest metabolism, is based on the amount of stored sugar and organic acids [58]. A lower level of respiration may, thus, contribute to the retardation of TSS [59]. In addition, nano- $\mathrm{TiO}_{2}$ can effectively resist the invasion of bacteria [29], thereby delaying the deterioration of blackcurrant quality.

A high TA content could be attributed to the chitosan coating's control over the permeability of $\mathrm{CO}_{2}$ and $\mathrm{O}_{2}$, which could slow the ripening rate of fruits [60] and the substrates for respiration responses, such as organic acids [13]. A reduced rate of respiration in fruits may be reflected in fewer changes in their TA. In this study, the CTS $+\mathrm{SA}+\mathrm{TiO}_{2}$ treatment more effectively inhibited the losses of TA in comparison with the other groups, which supports the findings of previous studies that chitosan combined with SA can greatly retain the content of TSS and TA [38]. The link between TA and ripening rate thus warrants closer investigation in future research.

Blackcurrants are an important source of $\mathrm{VC}$, however, much of this essential vitamin is typically lost during storage. According to the investigation of Xing et al. [22] and Xiao et al. [25], the loss of $\mathrm{VC}$ is promoted by the presence of $\mathrm{O}_{2}$ and $\mathrm{CO}_{2}$, but chitosan coatings can control the permeability of $\mathrm{CO}_{2}$ and $\mathrm{O}_{2}$ content in the microenvironment and further slow the rate of maturation. This explains the rapid decline of VC content in this study's CK group. As a water-soluble antioxidant, VC directly decreases the damage from reactive oxygen species (ROS) [61]. At the end of the storage period, the $\mathrm{CTS}+\mathrm{SA}+\mathrm{TiO}_{2}$ group was found to have the highest VC content, concurring with the results of Huang et al. [62], Sayyari et al. [63] and Shi et al. [64], who found that the application of SA in oranges, pomegranates and grapefruit reduced the degradation of VC. Furthermore, according to Shafiee et al. [65], SA could increase VC production by increasing the activity of ascorbate peroxidase, which effectively slows the decline of VC. Thus, in addition to the duration and conditions of storage, postharvest treatments also play an important role in VC changes [66].

\subsection{MDA Content}

MDA, an important product of membrane lipid peroxidation, has been found to aggravate membrane damage in fruits and vegetables, so its content can indirectly reflect the degree of damage to their tissue and membrane systems [32]. As can be seen in Figure 3, the MDA content in all groups showed a trend of continuous increase during the storage period; however, the rates of increase differed, with the CK group showing the fastest increase and reaching $9.25 \mu \mathrm{mol} / \mathrm{g}$ by the 30th day $(p<0.05)$. By contrast, the $\mathrm{CTS}+\mathrm{SA}+\mathrm{TiO}_{2}$ group showed the slowest growth of only $6.19 \mu \mathrm{mol} / \mathrm{g}$ MDA content in the same period $(p<0.05)$. The final levels of the other three treatment groups were $8.47 \mu \mathrm{mol} / \mathrm{g}(\mathrm{CTS}), 8.02 \mu \mathrm{mol} / \mathrm{g}\left(\mathrm{CTS}+\mathrm{TiO}_{2}\right)$, and $6.83 \mu \mathrm{mol} / \mathrm{g}(\mathrm{CTS}+\mathrm{SA})$, indicating that both chitosan and chitosan composite coatings can inhibit the production of MDA $(p<0.05)$. 


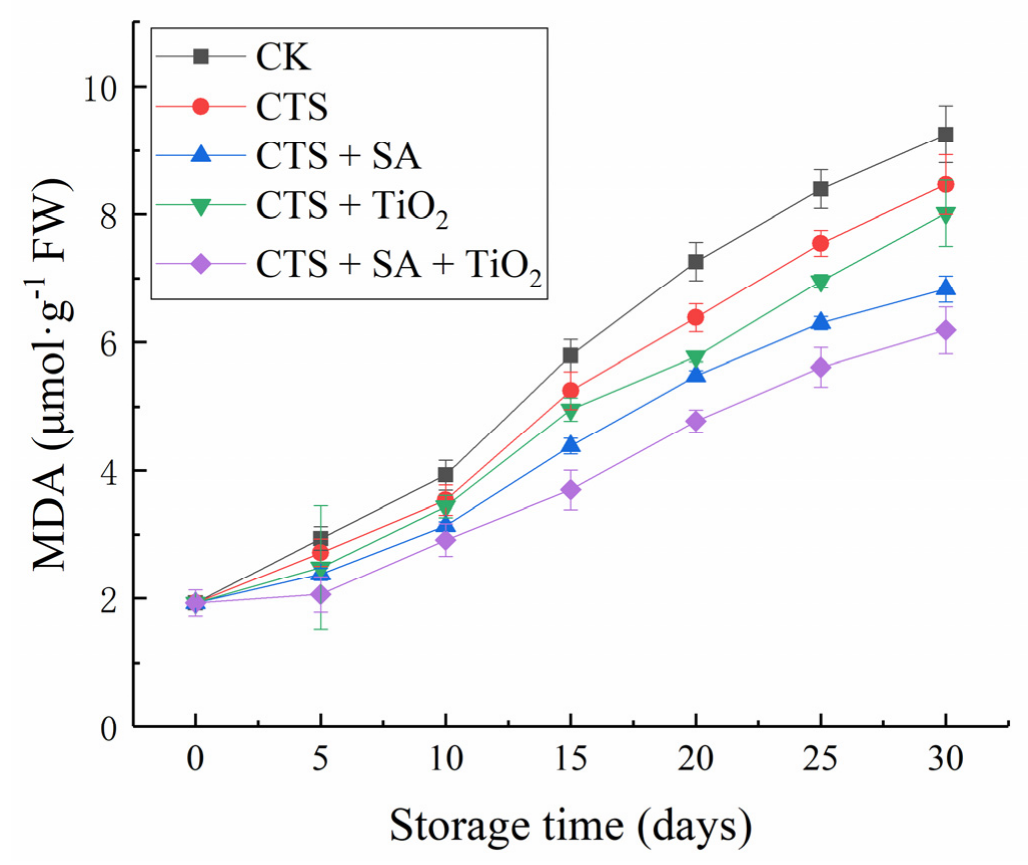

Figure 3. Effect of different coatings on the content of MDA in blackcurrant during 30-day storage at $4{ }^{\circ} \mathrm{C}$.

Postharvest fruit senescence involves a burst in the production of ROS, with cell damage such as lipid peroxidation resulting in the accumulation of MDA $[17,56,67]$. Here, as storage time increased, the blackcurrants gradually senesced, and their content of MDA increased. Compared with the CK group, those coated by chitosan and chitosan composited with $\mathrm{SA}$ and $\mathrm{TiO}_{2}$ exhibited a slow increase in MDA content $(p<0.05)$. Many studies have reported that chitosan treatment can increase enzymatic and non-enzymatic antioxidant systems to reduce ROS accumulation, thereby improving the quality and delaying the senescence of postharvest fruits $[46,68]$. In this work, the lowest MDA content was observed in the CTS $+\mathrm{SA}+\mathrm{TiO}_{2}$ group on the last day $(p<0.05)$, indicating that this composited coating effectively inhibited the accumulation of MDA, thereby reducing the degree of membrane lipid peroxidation [32]. Low MDA content was also found in the CTS + SA group. SA has the ability to delay senescence and reduce lipoxygenase activity [69], hence, the combination of chitosan and SA can effectively inhibit the deterioration of fruit quality. Nonetheless, as reported by Rasouli et al. [61], cold storage may lead to chilling injury, causing fruit cell membrane damage and, as the blackcurrants' storage in this study was at $4{ }^{\circ} \mathrm{C}$ for 30 days, this condition may have significantly influenced the changes to their MDA content.

\subsection{PPO Activity Analysis}

The PPO activities in blackcurrant fruits treated by different coatings during storage at $4{ }^{\circ} \mathrm{C}$ for 30 days were investigated. The results presented in Figure 4 show the same overall upward trend for all groups, indicating that both $\mathrm{CK}$ and coating-treated fruits can increase PPO activity during storage. Of the treatment groups, PPO activity increased fastest in the CK group, reaching $110 \mathrm{U} / \mathrm{g}$ by the last day $(p<0.05)$. The growth rate in the other four groups was relatively gentle, but the CTS group showed the fastest growth, reaching $104.69 \mathrm{U} / \mathrm{g}$ by the last day $(p<0.05)$. At the end of storage, the lowest PPO activity was observed in the CTS $+\mathrm{SA}+\mathrm{TiO}_{2}$ group, at only $98.88 \mathrm{U} / \mathrm{g}(p<0.05)$. 


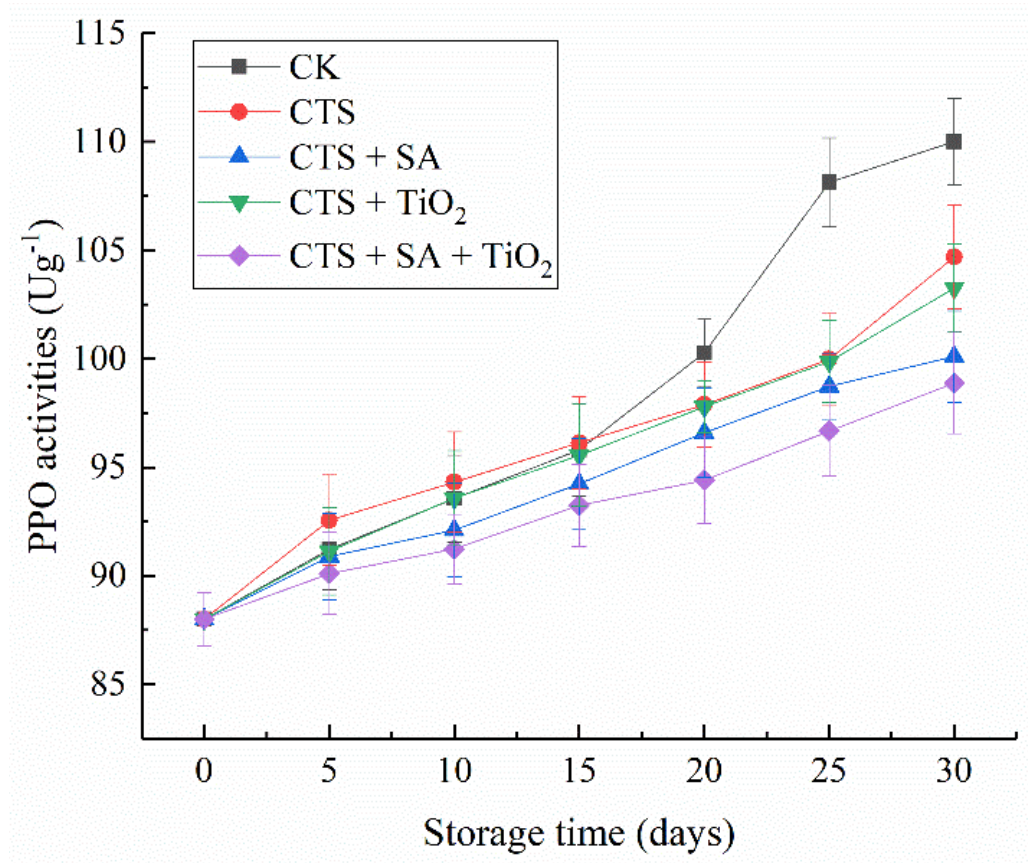

Figure 4. Effect of different coatings on the PPO activity in the blackcurrant during 30-day storage at $4{ }^{\circ} \mathrm{C}$.

The oxidation of phenolic substrates by PPO, which occurs during ripening, is believed to be a major cause of browning in many fruits and vegetables [51]. Enzymatic browning of phenolic substrates catalyzed by PPO is a symptom of the loss of membrane integrity during fruit senescence [41]. In concurrence, PPO activity in the chitosan and chitosan composite coated blackcurrants was found to be significantly lower than that of the CK group. The chitosan's inhibition of PPO activity and other biochemical reactions, which prevented the surface browning of the fresh blackcurrants, can be attributed to the low gas permeability of chitosan film, especially against $\mathrm{O}_{2}$ [70]. Furthermore, the coating can provide the ability to remove metal ions, further promoting the potential inhibition of PPO activity in blackcurrant fruits [22]. In this study, the groups treated with CTS + SA and $\mathrm{CTS}+\mathrm{SA}+\mathrm{TiO}_{2}$ coatings had the lowest levels of PPO on the last day $(p<0.05)$, which is consistent with the results of Tareen et al. [33]. Moreover, according to Xing et al. [40], the combination of chitosan and $\mathrm{TiO}_{2}$ could significantly inhibit PPO activity in stored mangos.

\subsection{TFC and TAC}

The TFC and TAC in blackcurrant fruit treated by different coatings at $4{ }^{\circ} \mathrm{C}$ for 30 days were investigated, and TFC was found to increases gradually in all groups (Figure 5a). At the end of the storage period, the highest content of TFC was observed in the CTS + $\mathrm{SA}+\mathrm{TiO}_{2}$ group, at up to $10.55 \mathrm{mg} \mathrm{RE} / \mathrm{g} \mathrm{FW}(p<0.05)$, followed by the CTS + SA (9.94 mg RE/g FW), CTS + $\mathrm{TiO}_{2}$ (9.81 mg RE/g FW) and CTS (9.54 mg RE/g FW) groups, respectively. TFC content was found to be lowest in the CK group on the last day, at only $9.18 \mathrm{mg} \mathrm{RE} / \mathrm{g}$ FW $(p<0.05)$. The changes in TAC are presented in Figure $5(\mathrm{~b})$. During the whole storage process, the TAC in the CK group increased continuously at first, reaching a peak of $44.78 \mathrm{C}-3-\mathrm{G} \mathrm{mg} / 100 \mathrm{~g}$ FW on day 25 , and then decreased rapidly to $32.03 \mathrm{C}-3-\mathrm{G}$ $\mathrm{mg} / 100 \mathrm{~g}$ FW by the final day. The TAC in the other four groups also increased throughout the storage period, and their contents on the last day (highest to lowest) were 43.31 C-3-G $\mathrm{mg} / 100 \mathrm{~g}$ FW (CTS), $42.59 \mathrm{C}-3-\mathrm{G} \mathrm{mg} / 100 \mathrm{~g}$ FW (CTS + SA + $\left.\mathrm{TiO}_{2}\right), 42.14 \mathrm{C}-3-\mathrm{G} \mathrm{mg} / 100 \mathrm{~g}$ FW $\left(\mathrm{CTS}+\mathrm{TiO}_{2}\right)$ and $39.55 \mathrm{C}-3-\mathrm{G} \mathrm{mg} / 100 \mathrm{~g} \mathrm{FW}(\mathrm{CTS}+\mathrm{SA})$. 
(a)

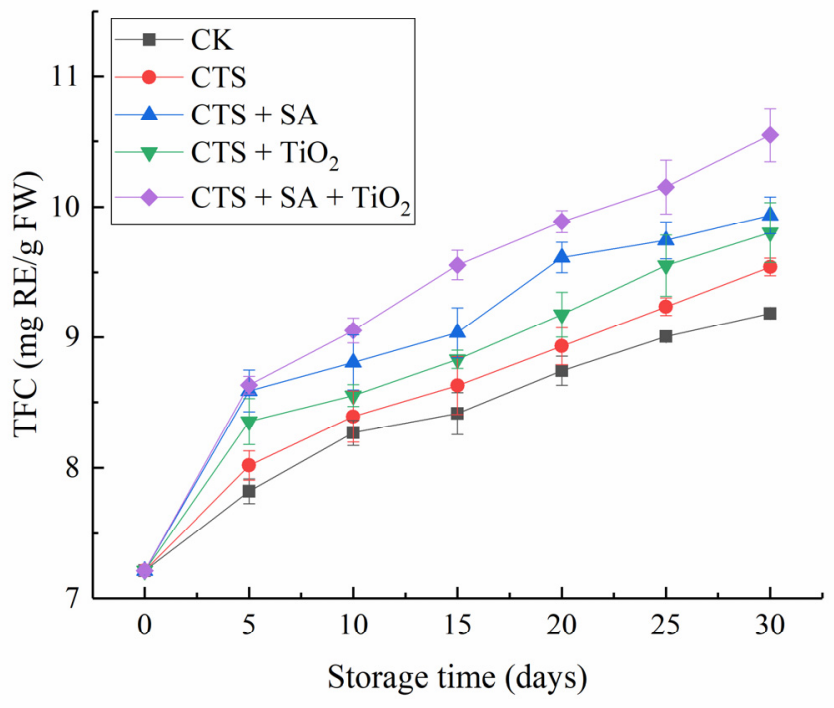

(b)

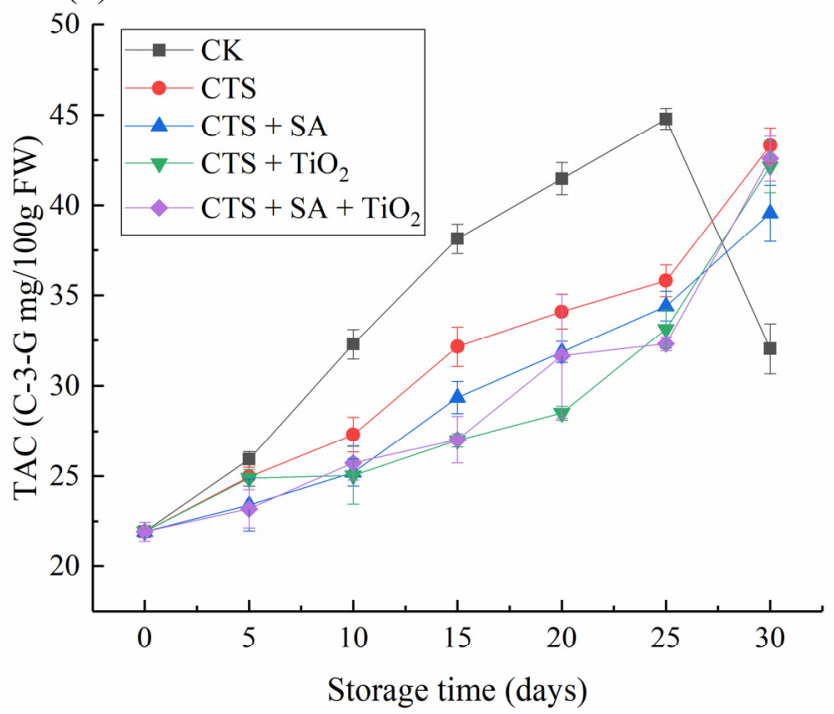

Figure 5. Total flavonoid content (a), anthocyanin content (b) of the samples during 30-day storage at $4{ }^{\circ} \mathrm{C}$.

Anthocyanins are a group of phenolic compounds responsible for the red-blue color of many fruits and vegetables, which provide beneficial effects for human health [71]. Flavonoids are secondary metabolites and derivatives of phenols, which exhibit antioxidant capacity [69]. Blackcurrants are one of the best sources of antioxidants among fruits and vegetables because of their natural flavonoid compounds and anthocyanin contents [72]. In the current study, the TFC and TAC of all treatment groups showed an upward trend during the storage period (as seen in Figure 5a,b). These findings concur with previous reports, and may be due to the continued biosynthesis of these compounds after harvest [71]. At the end of storage, the highest levels of both TFC and TAC were found in the CTS $+\mathrm{SA}+\mathrm{TiO}_{2}$ group $(p<0.05)$, indicating that this composite film could improve the preservation of anthocyanin and flavonoid content. This corresponds with the observations of Xing et al. [40], in which mango coated with chitosan film exhibited higher flavonoid levels after storage.

In this study, the fruits treated with the chitosan and chitosan composite coatings showed higher retention of TFC during the entire period of storage. Furthermore, the film with chitosan, combined with SA and $\mathrm{CTS}+\mathrm{SA}+\mathrm{TiO}_{2}$, performed best. The CTS + SA 
coated blackcurrants retained more flavonoids than other treatments, as the semipermeable coating of chitosan restricted moisture loss, gas exchange and senescence by modifying endogenous $\mathrm{O}_{2}$ and $\mathrm{CO}_{2}$ [69]. A reduced loss of TFC in response to pre-storage SA treatment was similarly reported in litchi [45], and chitosan was also reported to be highly effective in retaining higher TFC in treated grapes than the control [73]. On the other hand, these TFC and TAC might also be due to $\mathrm{TiO}_{2}$ nanoparticles, which are able to delay, retard or prevent the oxidation processes of flavonoids and anthocyanins by reacting with free radicals, chelating metals and acting as oxygen scavengers [40,74].

With respect to TAC (Figure $5 \mathrm{~b}$ ), the application of coating films was found to be highly effective in retaining anthocyanin pigments in the fruit pericarp $(p<0.05)$. All treatment groups exhibited incremental increases in TAC during storage, with the highest seen in the $\mathrm{CTS}+\mathrm{SA}+\mathrm{TiO}_{2}$ group $(p<0.05)$. In the $\mathrm{CK}$ group, after 25 days, the anthocyanin content had decreased rapidly due to the degradation of anthocyanin pigments, which consequently increased the incidence of pericarp browning. Moreover, the lack of coating treatment in the CK group facilitated a more rapid moisture loss than in the treated groups $(p<0.05)$, which, in turn, led to plasmolysis and the breakdown of membranes in the pericarp tissue. Consequently, anthocyanins present in the vacuole were released and encountered the enzyme anthocyanase and PPO, which further accelerated the degradation of anthocyanin pigments [45].

\subsection{Microbiological Analysis}

The quality of blackcurrants during storage is limited by the highly perishable nature of the fruit, including susceptibility to postharvest diseases associated with bacteria, yeasts and fungal infection [8]. The number of pathogenic colonies is, thus, a critical index to the quality of blackcurrants during storage. Figure 6 shows the effects of different chitosan treatments on the total viable counts in blackcurrants during storage. A total aerobic plate count showed that the total number of aerobic mesophilic microorganisms in all the samples was below the detection limit of $2.0 \times 10^{1} \mathrm{CFU} / \mathrm{g}$ on day 0 . The colony number in the CK group was higher than those of the other four groups throughout storage, finally measuring $3.34 \log \mathrm{CFU} / \mathrm{g}$ on the last day $(p<0.05)$, while the conditions of the other four groups were as follows: CTS (3.20 log CFU/g), CTS + SA (3.18 log CFU/g), CTS + $\mathrm{TiO}_{2}$ $(2.90 \log \mathrm{CFU} / \mathrm{g})$ and $\mathrm{CTS}+\mathrm{SA}+\mathrm{TiO}_{2}(2.67 \log \mathrm{CFU} / \mathrm{g})$.

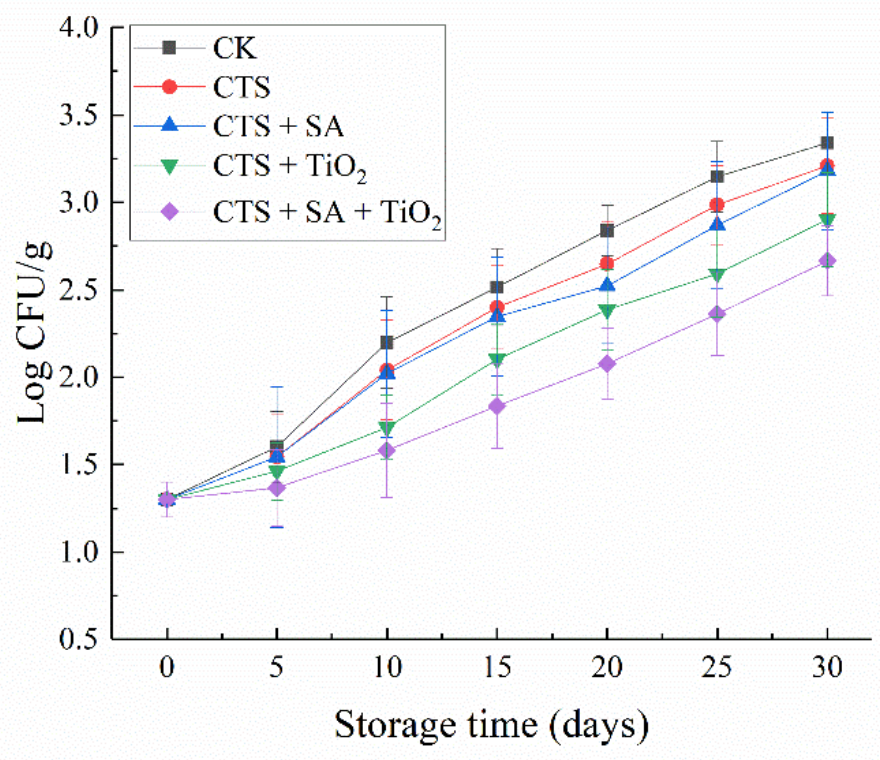

Figure 6. The colony units of each handle group in blackcurrants during 30-day storage at $4{ }^{\circ} \mathrm{C}$.

As shown in Figure 6, the CTS solution, both with or without nano- $\mathrm{TiO}_{2}$ or SA, seemingly inhibited bacterial growth, compared with the CK samples. Furthermore, the 
blackcurrants treated with CTS $+\mathrm{SA}+\mathrm{TiO}_{2}$ showed the best performance in terms of the total number of colonies $(p<0.05)$. To a certain extent, these results indicate that SA and nano- $\mathrm{TiO}_{2}$ treatment controlled the rapid growth of bacteria. According to MoscosoRamírez et al. [75], SA treatment showed antimicrobial activity in oranges, decreasing green and blue molds. It has also been shown that the exogenous application of SA increases the endogenous level of SA [64], thereby increasing antioxidant enzyme activities and the production of pathogenesis-related proteins in some plants [76]. $\mathrm{Nano}^{-\mathrm{TiO}_{2}}$ is also effective for inhibiting bacteria. According to the antimicrobial mechanism reported by Maneerat et al. [77], microorganisms carry a negative charge while metal oxides carry a positive charge, which creates an electromagnetic attraction between microbe and treated surface. Moreover, with $\mathrm{CTS}+\mathrm{SA}+\mathrm{TiO}_{2}$ coating as an outer membrane protective barrier, the entry of bacteria to blackcurrant fruit was prevented or slowed and the $\mathrm{SA}+$ nano- $\mathrm{TiO}_{2}$ might also kill or injure the bacterial colonies.

\section{Conclusions}

This investigation ascertained that different treatments with edible coatings could directly and positively influence the quality of blackcurrants in storage. In conclusion, a $\mathrm{CTS}+\mathrm{SA}+\mathrm{TiO}_{2}$ coating is eco-friendly and can be used for shelf-life improvement by maintaining quality and controls the development of decay in postharvest blackcurrants. In this study, the fruit treated with $\mathrm{CTS}+\mathrm{SA}+\mathrm{TiO}_{2}$ presented the smallest changes in weight loss, TSS, TA, VC and TAC, and the highest TFC. This combined treatment also significantly inhibited PPO activity during storage, and these treated samples displayed the lowest MDA content. Microbial analysis indicates that fruit treated with CTS alone, in combination with SA, in combination with $\mathrm{TiO}_{2}$, and in combination with both these active substances, showed bacteriostatic activity; however, $\mathrm{CTS}+\mathrm{SA}+\mathrm{TiO}_{2}$ treatment has the best antibacterial properties. These findings thus show that the application of chitosan-based coatings and $\mathrm{SA}+$ nano- $\mathrm{TiO}_{2}$ may provide an excellent method for maintaining the quality of postharvest blackcurrant fruits.

Author Contributions: Methodology and Investigation, T.Y.; Original draft preparation, Y.X. and T.Y.; Conceptualization, Q.X.; Writing-Reviewing and Editing, Y.W.; Data curation, X.G.; Supervision, X.W.; Software, S.Y.; Visualization, L.X.; Supervision, P.Y. All authors have read and agreed to the published version of the manuscript.

Funding: This work was supported by the Science and technology support program of Sichuan [2019YFN0174, 2018NZ0090, 2019NZZJ0028 and 2016FZ0019]; Science and technology support program of Yibin [2018ZSF002]; Chengdu Science and Technology Project- key research and development program [2018-YF05-00213-SN]; Sichuan Provincial Key Laboratory Open Fund Project [GR-2018-E-01]; and Innovation Team Construction Program of Sichuan Education Department [15TD0017].

Institutional Review Board Statement: Not applicable.

Informed Consent Statement: Not applicable.

Data Availability Statement: Not applicable.

Conflicts of Interest: The authors declare no conflict of interest.

\section{References}

1. Kahu, K.; Janes, H.; Luik, A.; Klaas, L. Yield and fruit quality of organically cultivated blackcurrant cultivars. Acta Agric. Scand. B Soil Plant 2009, 59, 63-69. [CrossRef]

2. Lister, C.E.; Wilson, P.E.; Sutton, K.H.; Morrison, S.C. Understanding the Health Benefits of Blackcurrants. Acta Hortic. 2002, 485, 443-449. [CrossRef]

3. Hayat, Q.; Hayat, S.; Irfan, M.; Ahmad, A. Effect of exogenous salicylic acid under changing environment: A review. Environ. Exp. Bot. 2010, 68, 14-25. [CrossRef]

4. Jung, K.; Fastowski, O.; Poplacean, I.; Engel, K.H. Analysis and Sensory Evaluation of Volatile Constituents of Fresh Blackcurrant (Ribes nigrum L.) Fruits. J. Agric. Food Chem. 2017, 65, 9475-9487. [CrossRef] [PubMed] 
5. Li, Q.; Chen, L.S.; Ding, Q.B.; Lin, G.H. The stable isotope signatures of blackcurrant (Ribes nigrum L.) in main cultivation regions of China: Implications for tracing geographic origin. Eur. Food Res. Technol. 2013, 237, 109-116. [CrossRef]

6. Anttonen, M.J.; Karjalainen, R.O. High-performance liquid chromatography analysis of black currant (Ribes nigrum L.) fruit phenolics grown either conventionally or organically. J. Agric. Food Chem. 2006, 54, 7530-7538. [CrossRef]

7. Gopalan, A.; Reuben, S.C.; Ahmed, S.; Darvesh, A.S.; Hohmann, J.; Bishayee, A. The health benefits of blackcurrants. Food Funct. 2012, 3, 795-809. [CrossRef] [PubMed]

8. Khoo, G.M.; Clausen, M.R.; Pedersen, H.L.; Larsen, E. Bioactivity and chemical composition of blackcurrant (Ribes nigrum) cultivars with and without pesticide treatment. Food Chem. 2012, 132, 1214-1220. [CrossRef]

9. Mannozzi, C.; Tylewicz, U.; Chinnici, F.; Siroli, L.; Rocculi, P.; Dalla Rosa, M.; Romani, S. Effects of chitosan based coatings enriched with procyanidin by-product on quality of fresh blueberries during storage. Food Chem. 2018, 251, 18-24. [CrossRef]

10. Jiang, H.J.; Sun, Z.M.; Jia, R.X.; Wang, X.Y.; Huang, J.Y. Effect of chitosan as an antifungal and preservative agent on postharvest blueberry. J. Food Qual. 2016, 39, 516-523. [CrossRef]

11. Sun, X.X.; Baldwin, E.; Bai, J.H. Applications of gaseous chlorine dioxide on postharvest handling and storage of fruits and vegetables-A review. Food Control 2019, 95, 18-26. [CrossRef]

12. Xing, Y.G.; Li, W.X.; Wang, Q.; Li, X.L.; Xu, Q.L.; Guo, X.L.; Bi, X.F.; Liu, X.C.; Shui, Y.R.; Lin, H.B.; et al. Antimicrobial nanoparticles incorporated in edible coatings and films for the preservation of fruits and vegetables. Molecules 2019, $24,1695$. [CrossRef]

13. Montaser, A.S.; Wassel, A.R.; Al-Shaye'a, O.N. Synthesis, characterization and antimicrobial activity of Schiff bases from chitosan and salicylaldehyde/ $\mathrm{TiO}_{2}$ nanocomposite membrane. Int. J. Biol. Macromol. 2019, 124, 802-809. [CrossRef] [PubMed]

14. Khan, I.; Tango, C.N.; Chelliah, R.; Oh, D.H. Development of antimicrobial edible coating based on modified chitosan for the improvement of strawberries shelf life. Food Sci. Biotechnol. 2019, 28, 1257-1264. [CrossRef]

15. Madanipour, S.; Alimohammadi, M.; Rezaie, S.; Nabizadeh, R.; Khaniki, G.J.; Hadi, M.; Yousefi, M.; Bidgoli, S.M.; Yousefzadeh, S. Influence of postharvest application of chitosan combined with ethanolic extract of liquorice on shelflife of apple fruit. J. Environ. Health Sci. Eng. 2019, 17, 331-336. [CrossRef]

16. Chien, P.J.; Sheu, F.; Lin, H.R. Coating citrus (Murcott tangor) fruit with low molecular weight chitosan increases postharvest quality and shelf life. Food Chem. 2007, 100, 1160-1164. [CrossRef]

17. Zhang, W.L.; Zhao, H.D.; Zhang, J.; Sheng, Z.T.; Cao, J.K.; Jiang, W.B. Different molecular weights chitosan coatings delay the senescence of postharvest nectarine fruit in relation to changes of redox state and respiratory pathway metabolism. Food Chem. 2019, 289, 160-168. [CrossRef]

18. Kaya, M.; Ravikumar, P.; Ilk, S.; Mujtaba, M.; Akyuz, L.; Labidi, J.; Salaberria, A.M.; Cakmak, Y.S.; Erkul, S.K. Production and characterization of chitosan based edible films from Berberis crataegina's fruit extract and seed oil. Innov. Food Sci. Emerg. Technol. 2018, 45, 287-297. [CrossRef]

19. Xing, Y.G.; XLi, X.L.; Guo, X.L.; Li, W.X.; Liu, Q.; Xu, Q.L.; Wang, Q.; Yang, H.; Shui, Y.R.; Bi, X.F. Effects of different TiO 2 nanoparticles concentrations on the physical and antibacterial activities of chitosan-based coating film. Nanomaterials 2020, 10, 1365. [CrossRef] [PubMed]

20. Kaya, M.; Cesoniene, L.; Daubaras, R.; Leskauskaite, D.; Zabulione, D. Chitosan coating of red kiwifruit (Actinidia melanandra) for extending of the shelf life. Int. J. Biol. Macromol. 2016, 85, 355-360. [CrossRef]

21. Hernandez-Munoz, P.; Almenar, E.; Valle, V.D.; Velez, D.; Gavara, R. Effect of chitosan coating combined with postharvest calcium treatment on strawberry (Fragaria $\mathrm{x}$ ananassa) quality during refrigerated storage. Food Chem. 2008, 110, 428-435. [CrossRef]

22. Xing, Y.G.; Lin, H.B.; Cao, D.; Xu, Q.L.; Han, W.F.; Wang, R.R.; Che, Z.M.; Li, X.H. Effect of chitosan coating with cinnamon oil on the quality and physiological attributes of china jujube fruits. Biomed. Res. Int. 2015, 835151. [CrossRef] [PubMed]

23. Zhang, W.L.; Li, X.X.; Jiang, W.B. Development of antioxidant chitosan film with banana peels extract and its application as coating in maintaining the storage quality of apple. Int. J. Biol. Macromol. 2020, 154, 1205-1214. [CrossRef] [PubMed]

24. Xu, W.T.; Peng, X.L.; Luo, Y.B.; Wang, J.A.; Guo, X.; Huang, K.L. Physiological and biochemical responses of grapefruit seed extract dip on 'Redglobe' grape. LWT Food Sci. Technol. 2009, 42, 471-476. [CrossRef]

25. Xiao, C.L.; Zhu, L.W.; Luo, W.; Song, X.Y.; Deng, Y. Combined action of pure oxygen pretreatment and chitosan coating incorporated with rosemary extracts on the quality of fresh-cut pears. Food Chem. 2010, 121, 1003-1009. [CrossRef]

26. Ratseewo, J.; Warren, F.J.; Siriamornpun, S. The influence of starch structure and anthocyanin content on the digestibility of Thai pigmented rice. Food Chem. 2019, 298, 124949. [CrossRef]

27. Duangkhamchan, W.; Siriamornpun, S. Quality attributes and anthocyanin content of rice coated by purple-corn cob extract as affected by coating conditions. Food Bioprod. Process. 2015, 96, 171-179. [CrossRef]

28. Xu, W.R.; Xie, W.J.; Huang, X.Q.; Chen, X.; Huang, N.; Wang, X.; Liu, J. The graphene oxide and chitosan biopolymer loads TiO 2 for antibacterial and preservative research. Food Chem. 2017, 221, 267-277. [CrossRef] [PubMed]

29. Karthikeyan, K.T.; Nithya, A.; Jothivenkatachalam, K. Photocatalytic and antimicrobial activities of chitosan-TiO 2 nanocomposite. Int. J. Biol. Macromol. 2017, 104, 1762-1773. [CrossRef]

30. Chan, Z.L.; Qin, G.Z.; Xu, X.B.; Li, B.Q.; Tian, S.P. Proteome approach to characterize proteins induced by antagonist yeast and salicylic acid in peach fruit. J. Proteome Res. 2007, 6, 1677-1688. [CrossRef]

31. Ramezanian, A.; Dadgar, R.; Habibi, F. Postharvest Attributes of "Washington Navel" orange as affected by preharvest foliar application of calcium chloride, potassium chloride, and salicylic acid. Int. J. Fruit Sci. 2017, 18, 68-84. [CrossRef] 
32. Gao, Y.; Kan, C.N.; Wan, C.P.; Chen, C.Y.; Chen, M.; Chen, J.Y. Quality and biochemical changes of navel orange fruits during storage as affected by cinnamaldehyde-chitosan coating. Sci. Hortic. 2018, 239, 80-86. [CrossRef]

33. Tareen, M.J.; Abbasi, N.A.; Hafiz, I.A. Postharvest application of salicylic acid enhanced antioxidant enzyme activity and maintained quality of peach cv. 'Flordaking' fruit during storage. Sci. Hortic. 2012, 142, 221-228. [CrossRef]

34. Dokhanieh, A.Y.; Aghdam, M.S.; Fard, J.R.; Hassanpour, H. Postharvest salicylic acid treatment enhances antioxidant potential of cornelian cherry fruit. Sci. Hortic. 2013, 154, 31-36. [CrossRef]

35. Siriamornpun, S.; Kaewseejan, N. Quality, bioactive compounds and antioxidant capacity of selected climacteric fruits with relation to their maturity. Sci. Hortic. 2017, 221, 33-42. [CrossRef]

36. Qiao, G.H.; Xiao, Z.G.; Ding, W.X.; Rok, A. Effect of chitosan/Nano-titanium dioxide/thymol and tween films on ready-to-eat cantaloupe fruit quality. Coatings 2019, 9, 828. [CrossRef]

37. Supapvanich, S.; Anan, W.; Chimsonthorn, V. Efficiency of combinative salicylic acid and chitosan preharvest-treatment on antioxidant and phytochemicals of ready to eat daikon sprouts during storage. Food Chem. 2019, 284, 8-15. [CrossRef]

38. Cui, K.B.; Shu, C.; Zhao, H.D.; Fan, X.G.; Cao, J.K.; Jiang, W.B. Preharvest chitosan oligochitosan and salicylic acid treatments enhance phenol metabolism and maintain the postharvest quality of apricots (Prunus armeniaca L.). Sci. Hortic. 2020, $267,109334$. [CrossRef]

39. Tian, F.; Chen, W.L.; Wu, C.E.; Kou, X.H.; Fan, G.J.; Li, T.T.; Wu, Z.H. Preservation of Ginkgo biloba seeds by coating with chitosan/nano- $\mathrm{TiO}_{2}$ and chitosan/nano-SiO 2 films. Int. J. Biol. Macromol. 2019, 126, 917-925. [CrossRef]

40. Xing, Y.G.; Yang, H.; Guo, X.L.; Bi, X.F.; Liu, X.C.; Xu, Q.L.; Wang, Q.; Li, X.L.; Shui, Y.R.; Chen, C.K.; et al. Effect of chitosan/Nano$\mathrm{TiO}_{2}$ composite coatings on the postharvest quality and physicochemical characteristics of mango fruits. Sci. Hortic. 2020, 263, 109135. [CrossRef]

41. Molamohammadi, H.; Pakkish, Z.; Akhavan, H.R.; Saffari, V.R. Effect of salicylic acid incorporated chitosan coating on shelf life extension of fresh in-hull pistachio fruit. Food Bioprocess Technol. 2019, 13, 121-131. [CrossRef]

42. Han, C.; Zhao, Y.; Leonard, S.W.; Traber, M.G. Edible coatings to improve storability and enhance nutritional value of fresh and frozen strawberries (Fragaria $\times$ ananassa) and raspberries (Rubus ideaus). Postharvest Biol. Technol. 2004, 33, 67-78. [CrossRef]

43. Xing, Y.G.; Xu, Q.L.; Li, X.H.; Che, Z.M.; Yun, J. Antifungal activities of clove oil against rhizopus nigricans, aspergillus flavus and penicillium citrinum in vitro and in wounded fruit test. J. Food Saf. 2012, 32, 84-93. [CrossRef]

44. Zhang, Y.Z.; Zhang, M.L.; Yang, H.Q. Postharvest chitosan-g-salicylic acid application alleviates chilling injury and preserves cucumber fruit quality during cold storage. Food Chem. 2015, 174, 558-563. [CrossRef]

45. Kumari, P.; Barman, K.; Patel, V.B.; Siddiqui, M.W.; Kole, B. Reducing postharvest pericarp browning and preserving health promoting compounds of litchi fruit by combination treatment of salicylic acid and chitosan. Sci. Hortic. 2015, 197, 555-563. [CrossRef]

46. Jiang, X.J.; Lin, H.T.; Shi, J.; Neethirajan, S.; Lin, Y.F.; Chen, Y.H.; Wang, V.; Lin, Y.X. Effects of a novel chitosan formulation treatment on quality attributes and storage behavior of harvested litchi fruit. Food Chem. 2018, 252, 134-141. [CrossRef]

47. Gao, Y.; Liu, Y.; Kan, C.N.; Chena, M.; Chen, J.Y. Changes of peel color and fruit quality in navel orange fruits under different storage methods. Sci. Hortic. 2019, 256, 108522. [CrossRef]

48. Ji, Y.R.; Hu, W.Z.; Liao, J.; Jiang, A.L.; Xiu, Z.L.; Gaowa, S.; Guan, Y.G.; Yang, X.Z.; Feng, K.; Liu, C. Effect of atmospheric cold plasma treatment on antioxidant activities and reactive oxygen species production in postharvest blueberries during storage. J. Sci. Food Agric. 2020, 100, 5586-5595. [CrossRef]

49. Xu, X.; Zhang, L.; Feng, Y.B.; Yagoub, A.A.; Sun, Y.H.; Ma, H.L.; Zhou, C.S. Vacuum pulsation drying of okra (Abelmoschus esculentus L. Moench): Better retention of the quality characteristics by flat sweep frequency and pulsed ultrasound pretreatment. Food Chem. 2020, 326, 127026. [CrossRef] [PubMed]

50. Johnson, J.; Collins, T.; Walsh, K.; Naiker, M. Solvent extractions and spectrophotometric protocols for measuring the total anthocyanin, phenols and antioxidant content in plums. Chem. Pap. 2020, 74, 4481-4492. [CrossRef]

51. Bico, S.I.S.; Raposo, M.F.J.; Morais, R.M.S.C.; Morais, A.M.M.B. Combined effects of chemical dip and/or carrageenan coating and/or controlled atmosphere on quality of fresh-cut banana. Food Control 2009, 20, 508-514. [CrossRef]

52. Barman, K.; Asrey, R.; Pal, R.K.; Jha, S.K.; Bhatia, K. Post-harvest nitric oxide treatment reduces chilling injury and enhances the shelf-life of mango (Mangifera indicaL.) fruit during low-temperature storage. J. Hortic. Sci. Biotech. 2015, 89, 253-260. [CrossRef]

53. Zheng, Y.S.; Zhang, Q.M. Effects of polyamines and salicylic acid on postharvest storage of 'Ponkan' mandarin. Acta Hortic. 2004, 632, 317-320. [CrossRef]

54. Chaemsanit, S.; Matan, N. Effect of peppermint oil on the shelf-life of dragon fruit during storage. Food Control 2018, 90, 172-179. [CrossRef]

55. Teerachaichayut, S.; Ho, H.T. Non-destructive prediction of total soluble solids, titratable acidity and maturity index of limes by near infrared hyperspectral imaging. Postharvest Biol. Technol. 2017, 133, 20-25. [CrossRef]

56. Luo, Z.S.; Chen, C.; Xie, J. Effect of salicylic acid treatment on alleviating postharvest chilling injury of 'Qingnai' plum fruit. Postharvest Biol. Technol. 2011, 62, 115-120. [CrossRef]

57. Zhang, Y.; Chen, K.S.; Zhang, S.L.; Ferguson, I. The role of salicylic acid in postharvest ripening of kiwifruit. Postharvest Biol. Technol. 2003, 28, 67-74. [CrossRef]

58. Wang, Z.; Ma, L.; Zhang, X.F.; Xu, L.M.; Cao, J.K.; Jiang, W.B. The effect of exogenous salicylic acid on antioxidant activity, bioactive compounds and antioxidant system in apricot fruit. Sci. Hortic. 2015, 181, 113-120. [CrossRef] 
59. Sayyari, M.; Castillo, S.; Valero, D.; Díaz-Mula, H.M.; Serrano, M. Acetyl salicylic acid alleviates chilling injury and maintains nutritive and bioactive compounds and antioxidant activity during postharvest storage of pomegranates. Postharvest Biol. Technol. 2011, 60, 136-142. [CrossRef]

60. Xing, Y.G.; Xu, Q.L.; Li, X.C.; Chen, C.K.; Ma, L.; Li, S.H.; Che, Z.M.; Lin, H.B. Chitosan-based coating with antimicrobial agents: Preparation, property, mechanism, and application effectiveness on fruits and vegetables. Int. J. Polym. Sci. 2016, 4851730. [CrossRef]

61. Rasouli, M.; Saba, M.K.; Ramezanian AJ, S.H. Inhibitory effect of salicylic acid and Aloe vera gel edible coating on microbial load and chilling injury of orange fruit. Sci. Hortic. 2019, 247, 27-34. [CrossRef]

62. Huang, R.H.; Xia, R.X.; Lu, Y.M.; Hu, L.M.; Xu, Y.J. Effect of pre-harvest salicylic acid spray treatment on post-harvest antioxidant in the pulp and peel of 'Cara cara' navel orange (Citrus sinenisis L. Osbeck). J. Sci. Food Agric. 2008, 88, 229-236. [CrossRef]

63. Sayyari, M.; Babalar, M.; Kalantari, S.; Serrano, M.; Valero, D. Effect of salicylic acid treatment on reducing chilling injury in stored pomegranates. Postharvest Biol. Technol. 2009, 53, 152-154. [CrossRef]

64. Shi, Z.J.; Wang, F.; Lu, Y.Y.; Deng, J. Combination of chitosan and salicylic acid to control postharvest green mold caused by Penicillium digitatum in grapefruit fruit. Sci. Hortic. 2018, 233, 54-60. [CrossRef]

65. Shafiee, M.; Taghavi, T.S.; Babalar, M. Addition of salicylic acid to nutrient solution combined with postharvest treatments (hot water, salicylic acid, and calcium dipping) improved postharvest fruit quality of strawberry. Sci. Hortic. 2010, 124, 40-45. [CrossRef]

66. Mditshwa, A.; Magwaza, L.S.; Tesfay, S.Z.; Opara, U.L. Postharvest factors affecting vitamin C content of citrus fruits: A review. Sci. Hortic. 2017, 218, 95-104. [CrossRef]

67. Cheng, S.C.; Wei, B.D.; Zhou, Q.; Tan, D.D.; Ji, S.J. 1-Methylcyclopropene alleviates chilling injury by regulating energy metabolism and fatty acid content in 'Nanguo' pears. Postharvest Biol. Technol. 2015, 109, 130-136. [CrossRef]

68. Silva, W.B.; Silva GM, C.; Santana, D.B.; Salvador, A.R.; Medeiros, D.B.; Belghith, I.; da Silva, N.M.; Cordeiro MH, M.; Misobutsi, G.P. Chitosan delays ripening and ROS production in guava (Psidium guajava L.) fruit. Food Chem. 2018, 242, 232-238. [CrossRef]

69. Saurabh, V.; Barman, K.; Singh, A.K. Synergistic effect of salicylic acid and chitosan on postharvest life and quality attributes of jamun (Syzygium cumini Skeels) fruit. Acta Physiol. Plant. 2019, 41, 89. [CrossRef]

70. Pasquariello, M.S.; Di Patre, D.; Mastrobuoni, F.; Zampella, L.; Scortichini, M.; Petriccione, M. Influence of postharvest chitosan treatment on enzymatic browning and antioxidant enzyme activity in sweet cherry fruit. Postharvest Biol. Technol. 2015, 109, 45-56. [CrossRef]

71. Sogvar, O.B.; Saba, M.K.; Emamifar, A. Aloe vera and ascorbic acid coatings maintain postharvest quality and reduce microbial load of strawberry fruit. Postharvest Biol. Technol. 2016, 114, 29-35. [CrossRef]

72. Xu, Y.Q.; Niu, X.K.; Liu, N.Y.; Gao, Y.K.; Wang, L.B.; Xu, G.; Li, X.G.; Yang, Y. Characterization, antioxidant and hypoglycemic activities of degraded polysaccharides from blackcurrant (Ribes nigrum L.) fruits. Food Chem. 2018, 243, 26-35. [CrossRef] [PubMed]

73. Shiri, M.A.; Bakhshi, D.; Ghasemnezhad, M.; Dadi, M.; Kalorizou, H. Chitosan coating improves the shelf life and postharvest quality of table grape (Vitis vinifera) cultivar Shahroudi. Turk. J. Agric. For. 2013, 37, 148-156. [CrossRef]

74. Xing, Y.G.; Li, X.H.; Zhang, L.; Xu, Q.L.; Che, Z.M.; Li, W.L.; Bai, Y.M.; Li, K. Effect of $\mathrm{TiO}_{2}$ nanoparticles on the antibacterial and physical properties of polyethylene-based film. Prog. Org. Coat. 2012, 73, 219-224. [CrossRef]

75. Moscoso-Ramírez, P.A.; Palou, L. Evaluation of postharvest treatments with chemical resistance inducers to control green and blue molds on orange fruit. Postharvest Biol. Technol. 2013, 85, 132-135. [CrossRef]

76. Wu, H.S.; Raza, W.; Fan, J.Q.; Sun, Y.G.; Bao, W.; Liu, D.Y.; Huang, Q.W.; Mao, Z.S.; Shen, Q.R.; Miao, W.G. Antibiotic effect of exogenously applied salicylic acid on in vitro soilborne pathogen, Fusarium oxysporum f.sp. niveum. Chemosphere 2008, 74, 45-50. [CrossRef] [PubMed]

77. Maneerat, C.; Hayata, Y.; Egashira, N.; Sakamoto, K.; Hamai, Z.; Kuroyanagi, M. Photocatalytic reaction of $\mathrm{TiO}_{2}$ to decompose ethylene in fruit and vegetable storage. Trans. ASAE 2003, 46, 725-730. [CrossRef] 